\title{
Chapter Five Publishing the Private, or The Economics of Experience
}

\author{
Sometimes it has occurred to me that a man should not live more than he can record, as a \\ farmer should not have a larger crop than he can gather in. \\ - Boswell: The Hypochondriack
}

Though the earth and all inferior creatures be common to all men, yet every man has a property in his own person; this nobody has any right to but himself

- Locke: Second Treatise on Civil Government

In a finely tempered and persuasive record of her encounters with Strindberg in Switzerland in 1884, Hélène Welinder recalls a conversation in which his young compatriot's sympathetic concern prompted the tired and harassed writer to describe the condition of almost permanent literary production in which he lived with unusual clarity. 'I cannot rest, even if I would like to,' he is reported as saying:

I have to write for my daily bread, to maintain my wife and children, and in other respects, too, I cannot leave it alone. If I am travelling by train or whatever I'm doing, my mind works without ceasing, it grinds and grinds like a mill, and I cannot stop it. I get no peace before I have put it down on paper, but then I begin all over again, and so the misery goes on. ${ }^{1}$

Whether or not the image of the remorseless and insatiable mill reached this quotation as a direct transcription of Strindberg's words is, of course, open to question. Nevertheless, even if it belongs entirely to Welinder's reconstruction, it is apposite, for it not only features frequently in Strindberg's later work as an image for the treadmill of conscience and the tenacity with which the past clings to the present; ${ }^{2}$ it also encompasses the suggestion that to write out what experience provides affords at best only temporary relief. But there is an additional complication at which it also hints, and which is inseparable from the publication of such writing, namely that in relieving himself of what he has lived, the professional writer consumes his experience and hence needs 
constantly to renew his primary material if he is not to become, or appear to become, 'written out'.

This tension between the pressures of 'writing out' and becoming 'written out' highlights a polarity which informs the whole of Strindberg's career. $\mathrm{He}$ is caught between the subjective drive which compels him to write ('and in other respects, too, I cannot leave it alone') and the inescapable exigencies of a market with which his inspiration and his fund of material may be out of step, and which either devours what he offers it and then demands more, or rejects his products as unsaleable. The law of supply and demand enters into an uneasy partnership with the fluctuations of inspiration, which sometimes flood the market when the latter is slack (and no market could accommodate the extraordinary series of sixteen plays, including To Damascus I and II, The Dance of Death, Erik XIV, and A Dream Play, which the prodigal Strindberg produced between 1898 and 1901) or remains unresponsive to its seasonal needs, or to specific commercial advantages as regards length, genre, style, and material.

A few weeks in the spring of 1888 are typical. Forced to produce a quantity of what he considers inferior material 'which could be sold as summer reading' (VII:80) merely in order to live, and speculating privately over the sale of several older works in manuscript to earn some ready money, ${ }^{3}$ Strindberg fears for his talent. He is casting about for an alternative source of income in order to escape the deleterious effects of overproduction 'in this age of specialists and the division of labour' (VII:82) when suddenly 'a narrative set in upper Sörmland (150 pages perhaps) called The Sexton in Vidala' (VII:89) erupts into a publishing schedule which is geared to the short pieces of Life in the Skerries (Skärkarlsliv), ${ }^{4}$ and it is only with some violence to the text in hand that the one can be reconciled with the other. Indeed, the new narrative, which becomes 'The Romantic Organist of Rånö', rapidly outgrows Strindberg's expectations: 'It was intended to be a trivial sketch of an uninteresting organist fellow,' he tells Bonnier, 'but has turned into something much more than that' (VII:103). Meanwhile another text is taking shape in events at Skovlyst where Strindberg is for the moment impecuniously and precariously lodged ('This will be a novel later' (VII:112) is his ominous comment to Edvard Brandes, when he sends him an interim report), and Miss Julie, which he shrewdly estimates is a work 'which will go down in history' (VII:104), remains unpublished even though he relinquishes every pretension to a reward which would be commensurate with what he recognizes is 'the flower of my production and of Swedish drama' (VII:106), and asks of Bonnier only the most meagre of returns, its labour cost at a subsistence rate of pay: 'My conditions are only the production costs for the manual labour (= one month of life)' (VII:104). 
Strindberg was, of course, aware that the reach of his talent and his productivity were too capacious and versatile for the restricted Swedish market, and he recognized a more appropriate stage for his labours in Berlin or Paris. 'My enormous productive urge (and the word Strindberg uses, produktionsdrift, indicates both an innate urge and its actual marketing) requires the book markets of several countries' (VI:80), he told the dubious Bonnier in 1886, and even if it meant forsaking his native language, he had frequently to live and to write accordingly. With a majority of his recent plays either unpublished or unperformed in Sweden, an essential aspect of his departure for the continent in 1892 was the need to discover new outlets for his work. 'After trying for so many years to live as a Swedish writer, I have realized it is impossible and am at crisis point' (IX:5), he informed a colleague earlier that year, and in the period which followed many works, among them Inferno, were fashioned and written either wholly or in part with a foreign public in mind, as he found himself once again a (not so) young man from the provinces laying siege once more to 'die Hauptstadt des XIX. Jahrhunderts'. And he knew enough not to arrive empty handed 'Am bringing 100 pages of a feuilleton in French with me', he told his contact in the city, Littmansson. 'Will start straight away with some sensational articles so that Paris will be astounded' (X:225). Worldly wise at least in this, he knew by now that the writer is his own product and must display himself spectacularly.

For his predicament was by no means unusual during a period in which the writer was generally confronted by what Goldsmith, a century earlier, had described as 'That Fatal Revolution whereby Writing is converted to a Mechanic Trade. ${ }^{5}$ Produced in private for an anonymous and dispersed public, and increasingly dependent upon the author's subjectivity for its matter (and the shift which Georg Lukács detects from the multifaceted participation in society of Goethe, Stendhal, and Tolstoy, to the writer's confinement to the specialism of his trade in keeping with the capitalist division of labour, is an essential element of Strindberg's career), ${ }^{6}$ writing in Europe becomes capitalized in the nineteenth-century: that is to say, as patronage recedes and it becomes impossible for literature to escape the general division of labour, the writer who seeks a living by his pen alone, puts his thoughts and feelings into circulation on the open market, where the work of art in which they are rendered purchasable, becomes another commodity, in competition with all the others.

This is a mill to which all is grist, but the process has rarely been so clearly expressed as in a letter from Balzac to his publisher, Mame, after a visit to the Grand Chartreuse. The experience had, he maintains, been profound and uplifting, but within a week he is writing: 
Redoublez d'attention Maitre Mame

J'ai été, depuis longtemps frappé et désireux de la gloire populaire qui consiste à faire vendre à des milliers incommensurables d'exemplaires, unpetit volume in - 18 comme Atala, Paul et Virginie, le Vicaire de Vakefield, Manon Lescaut, Perault, etc.

La multiplicité des éditions compense le défault du nombre de volumes; mais, il faut que le livre puisse aller en toutes les mains, celles de la jeune fille, celles de l'enfant, celles du vieillard et même celles de la dévote. Alors, une fois le livre connu, ce qui est long ou bref, selon le talent de l'auteur et (celui) du libraire, ce livre devient une affaire importante, exemple, les Méditations de Lamartine à 40000 ex(emplaires) et les Ruines de Volney, etc.

Mon livre est done un livre conçu dans cet esprit, un livre que la portière et la grande dame puissent lire. J'ai pris l'Evangile et le Catéchisme pour modèles, deux livres d'excellent débit, et j’ai fait le mien. J'ai mis la scene au village, et, du reste, vous le lirez en entier, chose rare avec moi.

In thus describing an as yet unwritten book (but which eventually appears as Le Médecin de campagne) Balzac promptly transforms a moving spiritual experience into an item for sale, citing the prolifically selling New Testament as one of his models and outlining the type of public at which it is aimed. And while, as a professional writer, he is immediately able to place it in terms of genre and style, and is certainly in no doubt that he can write this instrument of his 'gloire populaire' when he chooses so to do, as a businessman he can also gauge its sales potential and see it will prove a sound investment.

Throughout the Inferno period, it is clear that Strindberg is also constantly examining his experiences with a similar view to publication. From the outset he is intent on producing 'my book about everything I have "seen" and experienced since last December' (XI:193), and while he occasionally considers reverting to an earlier, pre-capitalist mode of publication by allowing the book to circulate only in manuscript (XI:323), his more practical schemes fluctuate between the novel and autobiography, the document humain and a work of speculative natural science. Moreover, however alarming the experiences he is monitoring become, there is no doubt that in seeking to interpret the enigmatic script of what he terms makterna, the capricious powers who seem to him in turn to be monitoring his life, he continues to function as an author, accustomed to publishing his experiences on a market that is, in its own way, equally capricious and enigmatic. On one level, the central phase of the Inferno period is inaugurated as a business project in which, with Torsten Hedlund as his agent back home in Göteborg, he secures a period of relative financial stability that allows him to conduct the experiments with the data of his own life which 
will eventually contribute so much to the text of Inferno, by ensuring, against various promisory notes of future writing, a privately donated sum of 1,200 kronor paid in monthly instalments by what he gathers is a group of business men, on occasion directly to the locations where the drama of his life is acted out, the Hotel Orfila and Mme Charlotte's Crêmerie (XI:135-8) where he sleeps and takes his meals. 'I propose this consortium as follows', he writes to Hedlund: 'that I write a series of [articles as] letters [for publication in Göteborgs Handelstidning], straight from memory and my notes, without taking your paper or its readers into account, but so that every letter can form a chapter in a book which, if you like it, I then offer you |the chance of publishing|, and for no honorarium if it does not promise to earn one' (XI:138).

Traces of this plan remain in the letters to Hedlund which Strindberg wrote between 6 and 22 July 1896 on manuscript paper rather than on the ordinary writing paper he used for several other more mundane letters to the same correspondent, paginated consecutively from 1 to 59 across the intervals in their composition.

These letters evidently encompass a provisional attempt to organize the material he later incorporated in the early chapters of Inferno, and already betray the ongoing process of artistic rearrangement of lived experience, for example in the account of his discovery of the French chemist Orfila, the instance of bibliomancy connected with the latter's book, and the general description of his predicament at the beginning of July, all of which is similar in tone and effect to the opening pages of Inferno (XI:245-6). ${ }^{8}$ And even if he claims only to be 'preparing a book in manuscript - which I am writing for myself and de Enkelte (Strindberg uses the Kierkegaardian term); without bothering about publishers, newspapers, old maids or the magistrate's court' (XI:388), he nevertheless also knew precisely when it was opportune 'to re-establish contact with life' (XI:310) and resume the profitable exploitation of his experiences in literature, once he had accumulated the necessary experience. Indeed, both the beginning and the end of the Inferno process as a whole demonstrate a remarkable combination of self-awareness and business acumen. The letter in which Strindberg initially reopened contact with Hedlund as the possible intermediary his future project would require, was written the day after he had sent his current intimate, Littmansson, the retrospectively significant information, 'What destiny now awaits me I do not know, but I feel 'The Hand of the Lord' resting upon me. It heralds a change upwards, or straight down to the centre of the earth, who knows!' (X:152), ${ }^{9}$ a clear sign that he intended a new departure, and it was followed by another in which he refers to his need for 'raw material in large quantities, observation, preferably my own, for I cannot depend upon other people's' (X:206-7). And having thus primed what proved to be an effective avenue to the support he needed, he was equally 
astute some two years later in recognizing when 'the period of grace' (XI: 304) afforded him by his backers was over and he had to 'take up the yoke again and work for my bread' (XI:303) by recommencing his literary career. Moreover, he revealed a similarly astute awareness of when this material had been fully exploited. In a letter to Gustaf af Geijerstam in March 1898, he admits what is so often the case with his projects, namely that he 'has miscalculated the extent of the manuscript' (XII:271) he has on hand. Although his current work, Jacob Wrestles, was not yet finished, he considered 'my religious conflicts at an end, and the whole Inferno saga over' (XII:271), and a few days later, impatient now to continue the playwrighting he has resumed in To Damascus, he contemplates a solution to the problem of his scanty copy which is no less mercenary in its implications than Balzac's plans for Le Médecin de campagne. Writing from Paris, he suggests:

A new plan!

On my journey to Lund (or Copenhagen) sometime early in April, depending on the money, I might stop off for a few days in a Benedictine monastery in Belgium to which I have been invited. I want to describe my impressions in Inferno II.

You can see that this will be a 'clou'.

So: a delay!

Why have a fiasco of a book, when we could have a success! To bore the public by reappearing with Part III in the autumn won't do! Two stout blows, and then full stop. (XII:278)

Thus as Lukács remarks, when discussing the novel in which this process is depicted most comprehensively, Balzac's Illusions perdues: 'From the writer's ideas, emotions, and convictions, to the paper on which he writes them down, everything is turned into a commodity that can be bought and sold ${ }^{10}$ Or to quote Arne Melberg, whose language permits the point to be made very neatly indeed, literature is now a fusion of work and commodity or verk and vara:

the nature of literature as work is determined by conditions in the sphere of circulation, where it also becomes an object and commodity. And the work (verket), as an aesthetic and meaningful unity (enhet), emerges as precisely a closed totality (helhet) in consequence of the market where it is forced to circulate as a commodity (vara). ${ }^{11}$

Melberg's formulation aptly indicates both the context in which the professional writer may produce his works under contract, to a specific length, and at so many words a day, in order to earn the going rate per page or column (and as Strindberg discovers, when he negotiates the asking price per sheet according to the number of spaces per line with his publisher and compares his rate with 
the fees several of his contemporaries can command, not all writers or subjects realize the same rate (III:288)), and the attempt by a minority of writers, like Baudelaire and Mallarmé, to detach the work of art from market forces by disclaiming its utility value. And yet, as Roland Barthes has pointed out, it is precisely in order to preserve the work of art from the rough and tumble of the market place that such writers are also drawn to stress the labour involved in writing as a value in itself. Gautier, Flaubert, or Gide, Barthes observed, 'substituer à la valeurusage de l'écriture, une valeur-travail... L'écriture sera sauvée non pas en vertu de sa destination, mais grâce au travail qu'elle aura couté. Alors commence à s'élaborer une imagerie de l'écrivain-artisan qui s'enferme dans un lieu légendaire, comme un ouvrier en chambre... passant à ce travail des heures régulières de solitude et d'effort.' ${ }^{12}$

The consequences of this situation are far-reaching. Whether it is shrouded in the notion of impassibilité or shamelessly solicits attention by parading the author's personality in public, the work in which the writer disposes of his qualities and abilities, as if they were objects he could give away, diminishes and impoverishes him. 'L'homme n'est rien, l'ouvre tout', Flaubert asserts, ${ }^{13}$ and from 'Le Chef d'œuvre inconnu' to L'Oeuvre and When We Dead Awaken or Mallarmé's 'Herodiade', numerous nineteenth-century works maintain that when the product is imbued with life, its creator dies to life. Once completed it enters upon a life of its own, and into a series of relationships with other texts and other men, in keeping with the ideas developed by Marx in the section on estranged labour in The Economic and Philosophic Manuscripts, where the dehumanizing consequences of the product's domination of its producer are so eloquently described 'The more the worker produces', Marx write 'the less he has to consume; the more values he creates, the more worthless he becomes; the more his product is shaped, the more misshapen the worker; the more civilized his object, the more barbarous the worker', and deprived of direct, immediate contact with his audience, the writer, too, is plundered by his creation and deformed by his revelations. As Marx goes on to write, in words that have a particular poignance where the autobiographer is concerned:

The worker places his life in the object: but now it no longer belongs to him, but to the object... What the product of his labour is, he is not Therefore, the greater this product, the less he is himself. The externalization of the worker in his product means not only that his labour becomes an object, an external existence, but that it exists outside him, independently of him and alien to him, and begins to confront him as an autonomous power; that the life which he has bestowed on the object confronts him as hostile and alien. ${ }^{14}$ 
Dispossessed of his identity by the initial estranging transfer of the self he seeks into the language in which it is sought, the autobiographer thus confronts himself in the work as an alien figure whose life resembles but is no longer his own, and as the market on which he is launched becomes more impersonal and his readership more dispersed, so there is a complementary tendency for the writer to grow more intimate and his books to become the increasingly personal explorations of private experience. On the one hand, there is the inhospitable, strange, and alien world dominated by the impersonal powers of the market, in which the imperilled self (and this is a theme in Jacobsen's Niels Lyhne and Hamsun's Hunger as well as of By the Open Sea and Inferno) lives as it were with no fixed abode, while on the other, the diminished social role to which he is restricted by specialization, hands the writer over to self-reflection and self-projection.

In part, this has to do with the role subjectivity plays in the competitive struggle for the attention of a public the writer has to woo. A form of self-advertisement, it is a way of marketing his product the individual consciousness seeks to distinguish itself, to affirm its incomparable originality and uniqueness. And if the style is the man, the man is what he produces. He develops, and the public purchases, a work that is identifiable with the name of its producer, a name that becomes associated with what he produces. He seeks to be unmistakable, and beyond a characteristic style, a personal matter is one means by which the literary work identifies its progenitor, selects its readership, and demarcates the boundary separating the property of one author from another. Thus, dependent as he is for his livelihood on the interest of the public, attention devolves upon the person of the author, upon the image of himself that his works project, either in the form of a direct and strident self -exposure, in which he lives shamelessly in the eyes of the public, or through the creation of biographical images within the work whereby, as 'The Son of a Servant' or 'Joseph K', the writer is identified. The art of scandal and provocation is therefore linked with the other arresting images of the writer, including what could be termed the canonical set of actions which a culture expects him to carry out, and the legend of himself which the writer creates is thus itself a literary fact, a constituent part of the work for sale, and one which plays a structural role in the formation of the text.

This notion of self-reflection and self-projection is central. Where a previous generation (and in Sweden it is the group of writers known as Signaturerna who 'are the last representatives within Swedish belles-lettres who exist as a literary grouping outside a literary institution that is determined by the demands of the market place') ${ }^{15}$ could write without attending to themselves (as Stig Torsslow suggests, 'they did not dream of being themselves - they did not even understand what that meant - but strove to write what criticism expected 
of them'), ${ }^{16}$ Strindberg is brought by what he once termed 'the application of mercantilism to literature' (4:206) to place the author's own tribulations and possibilities at the centre even of what is ostensibly an historical drama, Master Olof. ${ }^{17}$ Freed by private resources, a position at the university, or a civil service post, from the need to publicize themselves, the writers of the Signatur group were, according to their spokesman, Carl David af Wirsén, the Secretary of the Swedish Academy and Strindberg's long-standing opponent, preserved from the demoralizing effects of the professional writer's life, and not least from that loss of character for which Strindberg in all his provocative variousness and apparent instability, was so often accused, not least by Wirsén himself:

Being employed upon precise tasks in the service of the state has given character a healthy firmness, and the muses, whose appearance is as fleeting and unpredictable as it is sweet, have thus come unbidden and, as they love, shown their favours without having been troubled by importunate and indelicate requests to be present at all times. ${ }^{18}$

As he strove to establish himself as an independent man of letters. however, Strindberg recognized that 'even when he is recognized a writer is nothing in himself, but everything by virtue of the opinion others have of his talent' (37:151), and he therefore claimed that writers had 'always worked with a great deal of noise; if they have not succeeded in making that quantity of bruit at which they have aimed, they have once again vanished into the eternal silence. ${ }^{19}$ 'Rien n'est si désagréable que d'être pendu obscurément', as he was tempted to add to the title page of The Red Room; ${ }^{20}$ and hence the writer, if he is at all well known, becomes a kind of public property, even a public spectacle:

The writer is a person who appears in public. The public follows his apprenticeship and watches his progress. The newspapers follow his work both with affectionate care and microscopic attention. He walks a tightrope over a waterfall. As long as he goes elegantly, no one dares whistle. On the contrary, people outdo each other in their applause to show they have taste. But as a public, they cannot avoid feeling a certain, why not say pleasure, if he falls. $(16: 53)^{21}$

Thus, when he threatened 'to travel around in Sweden and show [him]self for money' (V:272, but the idea recurs, and finally as a metaphor for his career as a writer in the late prose text, 'The Inevitable' (46:71)), it was only an extension of this primary appearance before the public that Strindberg had in mind. Had he not already sought to exhibit himself in language, there would have been no question of this physical spectacle.

When, however, it is ostensibly the writer himself, or his pseudonymous representative, who is repeatedly launched upon the market, the situation 
wherein the writer makes a business out of his inner life becomes particularly transparent, especially when retailed with the nakedness with which Strindberg appears to display himself. ${ }^{22}$ Indeed, Strindberg generally regards private experience as a form of primary capital, to be accumulated and then invested in language. 'Better, however, an unhappy marriage than none at all. One goes through it and comes out more experienced than before, and experience is capital' (41:290), the literary entrepreneur, Smartman, maintains, at the close of Black Banners, and Strindberg, too, evidently considered the events he sometimes instigates in order to acquire the material he needs for his work as kapital (capital) to be transformed into kapitel (chapters). 'Well, I got a new chapter out of it' (I:151), he remarks, after parting from an early mistress, much as when the hero of the late autobiographical novel, The Cloister, salvages his sinking courage on the way to meet his estranged wife's family by adopting 'as usual the writer's point of view: "If I don't come out of this with honour, I shall at least get a chapter for my novel!"' (C:92). Or as he observes again, some five pages later, when he relates how he 'went out to botanize and look at the landscape, and worked himself up into an irresponsible creative mood in which he thought about the piquant aspects of the situation: "This is a scene which no one has experienced before! It is mine, even if it's going to make my skin smart"' (C:97).

It is such 'collections of experienced material' (18:274 - materialsamlingar av erfarenheter), as he calls them, which form the basis of his production, and either immediately or in due course, they are turned to his account by a talent which authorizes the accumulation of experience irrespective of the cost to others which its exploitation occasions. 'He considered his talent was also a kind of capital; even if it brought no profit now, it gave him the right and duty to live whatever the cost' (19:27), he explains in The Son of a Servant, just as he later confesses that 'for me life is only material for dramatic works, ${ }^{23}$ and acknowledges in a diary entry for 25 January 1901 that 'if my life had passed calmly and quietly, I would not have had anything to relate.' Moreover, as a practising author he prides himself on the ability to perceive not only what is valuable in experience, but also how it should best be utilized. Hence the delight with which he realizes that some events, for example Dagny Juel's appearance in Berlin, come ready cut and trimmed (klippt och skuret) for literature ('Oh it's a novel!' (IX:188) he exclaims, with relish) or fall into the appropriate literary form when exposed to a tutored ear. In the Vivisection 'La Genese d'une Aspasie', the accomplished man of letters instructs the novice: 'Installé dans la même maison le maître dédie une éducation complète au petit, le fait narrer sa vie, lui indique où gisent les motifs avantageux. "C'est du théâtre, lui enseignet-il; voici une nouvelle; voila un roman”" (VR:22) 
The experience behind such mastery is intimated early in The Cloister, which opens with the writer reflecting upon recent events: 'By lying in bed and chewing over his experiences like this, he converted them into literary currency, and thus engraved or riveted them so securely on his mind that he could draw on them for future use as safely as if they were funds deposited in a bank' (C:14). Again the image is characteristic. Nothing may be squandered: the trace of every event is jealously guarded and, his spendthrift inspiration notwithstanding, Strindberg frequently refers to this steadily augmented basic capital in terms of prudent literary house-keeping. For the question is often how much he has in his current account and how much is deposited for the future or lying unused or unexploited in the form of already written but unpublished or out of print works that represent 'dead capital' (V:278) on which he demands the 'interest' (IX:205) due to him. Thus when writing The Son of a Servant he deliberately leaves certain motifs on the shelf. This is particularly the case with his experiences on the island of Kymmendö in the Stockholm archipelago, and with the history of his first marriage. For the time being both are allowed to gather interest, but in May 1886 he tells Bonnier that 'when I have finished part II, I have been thinking of writing a little book of Swedish idylls for the Christmas trade... These are savings (sparpenningar) from The Son of a Servant, in which the scenery has been intentionally neglected' (V:320), and some six months later he already sees their realisation in 'a Swedish rural novel in which I shall invest my large reserve fund from Kymmendö, which I have not used as long as I had hopes of returning there again', adding, with a rare and passing tolerance: 'To be sure, young Geijerstam has drawn a small compulsory loan on my fund, but I have seven years' savings and so many feathers left that I can donate a little down to the goslings' (VI:122). As for the history of his marriage, he merely remarks, darkly: 'We'll come back to the matter'.

This attitude to the relationship between the writer's work and his lived experience is not, of course, unique to Strindberg. At about the same time, Victoria Benedictsson wrote to Axel Lundegård that 'we writers have no other capital to draw on than our knowledge of human nature. This is therefore the capital which we must accumulate', ${ }^{24}$ and Béatrice Didier has recently written persuasively of the way in which the intimate journal becomes a deposit account for 'le capital fondamental: le moi' ${ }^{25}$ as it is augmented or misspent from day to day. But in Strindberg's case, rooted as it so firmly is in the spirit of Protestantism to which Didier often alludes in her analysis, it is exacerbated by his pronounced sense of property rights, both as regards his own person and the ideas he entertains. Writing, which acts as a daily inventory in which he monitors the debit and credit of his account with the world, is also entrusted (and not only in the period when he was preoccupied with the notion of a 'battle of the brains') with the preservation of the writer's intellectual domain. 
'It is surely the case', he argues, in the late essay, 'The Mysticism of World History'

that when someone has adopted an opinion or viewpoint, it is somehow assimilated into their person and becomes a property which at first requires defending, and then that one goes on to the attack in order to increase it, like any other type of property. To surrender one's opinion to another's is really like being conquered, becoming another man's slave, and one does not want that to happen. (54:370)

Thus the intensity with which Strindberg maintained the principle that 'what one has oneself experienced is of course one's own, and he who wishes to take it away from one is a thief (X:216), and hence the lasting aggravation to which he was provoked by an embezzler of other people's experience such as Gustaf af Geijerstam, whom he repeatedly accused of filching his material. ${ }^{26}$ For if, as The Unknown declares, 'what I have lived through is mine and no one else's, then 'what I have read has (also) become mine, because I broke it in pieces like glass, melted it down, and out of the shapeless mass blew new glass in new forms' (29:322), and Strindberg consequently resents all interference with his script since, once written, it has the creditworthiness of any more orthodox financial transaction: 'Altering a text which is signed by an author ought really to be considered tantamount to altering the value of an accepted bill of exchange' (54:236).

However, the kind of conspicuous consumption of private experience in which Strindberg engages is ultimately a form of self-consumption. Paradoxically, in displaying his riches so generously, he periodically impoverishes himself and needs to replenish his resources. 'My purpose in travelling to Berlin', he informs Schering, 'is for study and to get some new ideas, for here the sleep of winter prevails all the year round, and I have lived up the whole of my stock which I brought back from abroad the last time' (XIV:220). For the kind of primary capital accumulated in lived experience or drawn from other books (and topping up experience could be expensive, as Strindberg indicated to Bonnier apropos the story 'Rebuilding' (Nybyggnad): 'the novella is composed, studied (I have read 100 francs worth of books)' $(\mathrm{V}: 8))$ is rapidly exhausted, and a professional writer such as Strindberg elected to be, is forced, as Waiter Berendsohn once pointed out, continually to

look about him for a new motif, which stimulated and attracted him, but which also saved him from repeating himself and boring his readers. Originality, not to come again with the same thing, to be new and in the vanguard of intellectual development, are clearly conscious demands, which he placed upon himself and his creativity. ${ }^{27}$ 
Always afraid of 'falling behind' (V:343 - att bli på efterkälken) in the advance of contemporary ideas, this is one reason for the apparent inconsistency of Strindberg's work, its frequent shifts in direction, the rapid introduction of new subjects, styles, and genres, the continual enticement to experiment with fresh standpoints, to change his mind, his place of residence, or even his wife, in accordance with the modernist doctrine that Baudelaire formulated so succinctly:

Plonger au fond du gouffre, Enfer ou Ciel qu'importe?

Au fond de l'inconnu pour trouver du nouveau! $!^{28}$

As the autobiographical persona of the barely fictional narrative "Sequestration Journey" (Kvarstadsresan) points out, 'All my work is only a matter of changing opinions' (17:18), in part because - as Strindberg once expostulated to Littmansson - 'It must be new! New!' (X: 189), and the consequences of such an attitude are to be found in $A$ Madman's Defence, fruit of 'an experimental psychological investigation' that is ostensibly undertaken 'merely to enrich my literary fund' (VI:242), in The Cloister, where Axel has 'consumed most of his experiences' (C:73) and therefore sets out to replenish his stocks by finding what Strindberg at the time liked to call 'novels in reality' (IX:104), or in Inferno where, already adept at cultivating sickness and passion in himself in pursuit of the truthfully observed motif, he commences his return to literature by adopting the mood of deceptively casual receptivity that he attributes to Axel in The Cloister:

I have no opinions, only impromptues, and life would become pretty monotonous if one were to think and to say the same thing every day. It must be new; the whole of life is after all only a poem, and it is much more amusing to float over the swamp than to stick one's feet down and search for firm ground, where none exists. (C:58)

On occasion, at least, this was the spirit in which he embarked for the continent in 1892 to fill what became known as 'Gröna säcken', the green canvas bag into which he put his notes and scientific records, and the seemingly directionless period in Berlin, his short second marriage included, emerges as a time in which Strindberg accumulates the capital of experience without at first knowing how to make use of it in literature. It offers an image of Strindberg as the plaything of chance, at drift, allowing events to happen to him ('I feel liberated, drifting on the surface of a sea' (28:10), he recapitulates this mood later) but trawling fresh matter to replace his exhausted copy. 'I act by improvising; that makes life more amusing' (28:78), he explains, and while his striving for some kind of transmutation certainly retains a role for the improvident goldmaker with which his existence during this period is most dramatically associated, 
it is pertinent to notice that the immediate crisis is artistic, a combination of factors to which Strindberg, with his acute feeling for the pulse of literary history, was especially sensitive. ${ }^{29}$ Sensing that 'the naturalistic period... has now come to an end' (28:182), and in any case no longer wishing to locate himself in a moral and intellectual framework with which he had never been entirely at ease; responsive to the challenge which Verner von Heidenstam's literary manifesto, Renässans, directed against his already eroded standing in Sweden; ${ }^{30}$ encouraged by the example of Przybyszewski's and Munch's artistic experiments in Berlin and his acquaintance with Gauguin and the Symbolists in Paris, where he discovered an art that was alert to 'l'inépuisable fond de l'universelle analogie' ${ }^{31}$ and not prostrate before the superficial transcription of external reality (and as he told Hedlund 'I abandoned writing literature to avoid being superficial' (XI:138)), he 'commence aussi à sentir un besoin immense de devenir sauvage et de créer un monde nouveau'. ${ }^{32}$ In short, he recognizes the need to renew a genre which he had himself brought to fruition in Miss Julie and Creditors, and his 'Inferno Crisis', with its issue in the achievement of To Damascus and A Dream Play, is thus undoubtedly best apprehended in the light of Boris Eichenbaum's shrewd judgement upon an analogous and contemporary case: 'At the core of all Tolstoy's crises lies the search for new artistic forms and for their new rationale. ${ }^{33}$ And if this new rationale is to be seen as fundamentally 'mystic', as is now sometimes the case, then it is worth remembering that, as A. G. Lehmann wisely points out in his study of Strindberg's French contemporaries: 'mysticism affects aesthetic theory not by enabling its adepts to 'believe anything', but by giving them, or attempting to give them, an explanation why they find art valuable at all. ${ }^{34}$

For the process of self-consumption inherent in his Naturalist aesthetic frequently overwhelms Strindberg with feelings of disgust that extend to his practice as a writer in general. In a letter of 1898 he described himself as someone who 'gehe... wie ein Menschenfresser und Henker herum. Welch' ein Lebensberuf Schriftsteller zu sein: wie ein Fleischhauer töten und verkaufen' (XII:342), a description in which the characteristic conflation of text and flesh recalls both the famous quatrain from his volume of poetry, Sleepwalking Nights:

Där hänger på boklådsfönstret

en tunnklädd liten bok.

Det är ett urtaget hjärta

som dinglar där på sin krok. (13:209)

(There hangs in the bookshop window / a thinly clad little book. It is a gutted heart / which dangles there on its hook.) 
and the even earlier critical observation on another writer from 1876: 'A writer is not a writer just because he has written a book, for he has not had the courage to give his own blood, give a piece of his own inner life, instead of those events he has only encountered by chance. It is a grisly task to place one's heart on a montre. It is the cruelest kind of sacrifice to be a writer - but that is how it is! ${ }^{35}$ And these doubts, shored up as they are by the notion of self-sacrifice, are only compounded when he recognizes the impossibility of writing openly of himself without encroaching upon the property of those about him, an anxiety which informs the account of the writer's life presented in The Cloister, where Axel's consumption of his outstanding experiences reveals (if somewhat disingenuously, since the book implicitly in question, A Madman's Defence, had in fact been written by Strindberg some years earlier and in different circumstances to those in this retrospective reconstruction of his life) how exhaustion and poverty compel him to encroach upon a proscribed domain:

Approaching penury had forced him to sit down unwillingly to write, but as he had consumed most of his experiences he was obliged to misappropriate a subject that was really proscribed. He suppressed his own feelings, overcame all discretion, and began. (C:73-4)

The irony of the situation, in which the writer who preys upon himself and offers up his flesh for others to consume also battens upon those close to him and devours them like a cannibal or vampire, is in this case multiple. In order to provide both for his previous wife and children, and for his new attachment, the only narrative he has on hand is 'the merciless portrait of his first marriage' (C:75). Unable to produce a new work, in part because the already written account of this marriage so disgusts him, and quite unable, too, to invent or imagine a text with no basis in his experience, the unpublished book is nevertheless his only immediate means of support. And yet, by publishing it, his revulsion at his trade as a writer becomes too great even for the role of scientific vivisector which he evolved during the 1880 s to exonerate him from writing as he does so explicitly of others. Torn between the morality of telling what he regards as the truth and the immorality of publishing the private (or put another way: unable to reconcile himself to satisfying the demands of a voracious market by continuing to prey upon himself and others), he now experiences how

... the increasing distaste which he had for some time felt for his profession as a writer developed into an abhorence.

What an occupation: to sit and flay one's fellow human beings and then offer their skins for sale and expect they should buy them. To be like the hunter who in his hunger hacks off his dog's tail, eats the flesh himself and gives the dog the bones, his own bones. To go about spying 
out people's secrets, to betray one's best friend's birthmark, use one's wife as a guinea pig (vivisektionskanin), behave like a Croat, chop down, defile, burn and sell. $(\mathrm{C}: 130-1)^{36}$

Thus it is that when Strindberg attempts to recapture the spirit and ideas of the years leading up to his Inferno crisis, in a narrative that is inevitably coloured by his later experiences, his representative in the book, Axel, is already depicted as trying consciously 'to purge himself from the leaven of Naturalism' (C:20) which produced so brutal a book as A Madman's Defence, at the same time as he is shown up as the unwilling writer of such a book because unlike Strindberg when he came to review these years, he has not yet developed an alternative way of seeing the world.

\section{II}

Whatever the anachronistic obscurities of The Cloister, however, it is not surprising that as the most transparent and far-reaching example of his naturalistic art, A Madman's Defence should so compel Strindberg's attention. Of all his works, it is the one which disturbs him most, and it intrudes into many other texts besides The Cloister, where he claims it was 'written in selfdefence and as a testament, because in finishing it [he] intended to take his own life' (C:79). Obliquely, its presence is already felt in Creditors, where Tekla uneasily deflects discussion of the book she has written about her first marriage (23:253); it reappears, unexpectedly but appropriately, in Black Banners, in Zachris's plans for the publication of a similar story in Germany 'if pressed by necessity' (41:214 - A Madman's Defence was, of course, first published in Germany as Die Beichte eines Thoren); and it is also a central motif in To Damascus I where, as the embodiment of his guilt and of his misused talent, it relates The Unknown's situation in the first scene to the hiatus in his literary career which comes to light when he admits 'I am bankrupt, for I have lost the ability to create' (29:101) partly as a result of his most recent book, the account of a previous marriage which he forbids his companion to read. It is only when he acknowledges this link between his guilt and his literary impotence that he begins his progress along the road to Damascus, and towards the rationale which provides him with the basis of a new art.

Moreover, Strindberg's often contradictory and perplexing, sometimes ingenious, and on occasion deliberately misleading comments on the book between 1887 and 1894, indicate the continual disquiet, embarrassment, and uncertainty it caused him, not only as regards the propriety of what he had done in writing so intimately and with such venom of the private life he shared with others (and here the barbarous deformation of the producer referred to by Marx in his account of alienated commodity production is again a relevant 
factor), but also as to what kind of writing the book represents, to which domain, public or private, it belongs, its genre, who should read it, where, and in what language and what form. For beyond what the book reveals of Strindberg and his intimate life is what it conveys of the nineteenthcentury literary institution, of the writer's confinement to a largely private sphere of existence, and the conflict between the exploitation in literature of private material and the economic necessity of its publication, a conflict accomplished by a shift in public expectations, which now anticipate the lineaments of the author in every kind of literary text.

If combining what Zola terms 'une méthode chirurgicale, s'appuyant sur la science, aidant la science ${ }^{37}$ with a Kierkegaardian sense of duty seems to sanction his right as a writer 'to intervene with his time-honoured freedom in human lives and destinies, as a calling and a duty' (37:108), and thereby to satisfy 'the spirit of the time [in its challenge] to write about the living and not the dead' (VI:191), then Strindberg feels justified in overturning the reticence of a previous generation (and the shift can be observed in a comparison with Trollope's remark in his autobiography: 'My marriage was like the marriage of other people, and of no special interest to anyone except my wife') $)^{38}$ and publishing what he originally called the 'Histoire de mon marriage', a work he claimed was 'plus sincére que toute le reste' (X:86) and warranted because 'it is my story stark naked... It is a terrible book, but it is a true one' (VIII:188). Initially he regarded it as 'a whole original novel in French' (VI:381) which, with Zola in mind, he often called his 'Oeuvre', ${ }^{39}$ and in March 1888 he was already sounding out Hans Österling with a view to publication. His approach even hints at the category into which the work might fall: 'Do you dare take a French novel, set in Sweden, as indiscreet as [Hans Jæger's Fra] KristianiaBohêmen, but tremendously good, and which cannot or may not ever be published in a Scandinavian language' (VII:33) $?^{40}$ But the proviso already indicates a reservation. If, as Sven Rinman infers, ${ }^{41}$ a foreign language gave him an essential, uninhibiting distance to his material which enabled him to write the book in the first place, Strindberg also wrote in French because he knew that "when a work creates a scandal in its country of origin, it only has to cross the frontier where one no longer knows the "local circumstances" and it becomes literature' (16:48). ${ }^{42}$

But while a foreign language might suggest a wish to shield the feelings of those about whom he wrote, it also had practical advantages. As he explained to his cousin, the manuscript 'consists of 350 quarto pages, in French, for the dual purpose of keeping completely unauthorized people out of the matter, and so that it may not come under the heading of a Swedish manuscript, which according to certain contracts would fall to my publisher' (VII:43). And when he tried to interest the French publisher, Albert Savine, in the book, 
it was certainly not least this Scandinavian public that he envisaged among its potential readership: 'D'ailleurs et pour fixer le nombre des exemplaires à imprimer, il faut vous dire que vous pouvez compter sur mon public entier en Suède, Norvège, Danemark et Finland, en égard à ce qu'une édition en langue Scandinave ne sera jamais publiée' (VIII:371). While he continued to describe A Madman's Defence as a novel when expedient, however, the very fragility of its almost diaphanous fictional guise caused him to contemplate an alternative future for the text by playing down its literariness and stressing its documentary, even its testamentary, character as an 'Ehrenrettung' (VII:42), composed 'in the face of death' to claim his own redress, repudiate 'the fable that I was mad' (VII:48), and correct his strategy in texts such as The Father, in which he maintained he had 'lead opinion astray on purpose in order to conceal the real situation' (VII:47). 'Ce n'est pas un roman,' he told an unknown correspondent in 1893, 'ni un livre dans le sens propre de ce mot, c'est plutôt un fragment d'une vie agitée, et ce volume, écrit devant la mort; déposé chez des parents sous le sçeau pendant deux ans il fut destiné à servir comme document de famille pour l'avenir, je n'avais jamais l'intention de le faire imprimer' (IX:339), and in fact, three days after his letter to Österling of March 1888, he had already informed Edvard Brandes that he was working on 'my history, which will never be published, but will be read in manuscript by my surviving [relatives]' (VII:36). Moreover, when he took the extraordinary precaution of sending the book in manuscript to his cousin, Johan, and (thereby covering himself against misreport, and the text against misrepresentation) also to Heidenstam, the accompanying letters described it as 'a document to be deposited in the family archives... to enlighten posterity about the situation, provided that violent measures do not compel me to disclose everything immediately to my contemporaries' (VII:43). And such was the uncertainty surrounding the domain of this text in the minds of Strindberg's contemporaries as well as in his own, that as a submission for the defence in the mysterious prosecution brought against the book in Germany, this family letter was indeed accepted as evidence that it was neither a novel nor intended for publication.

Whatever the purpose he attributed to the book, however, the moral dilemma in writing and publishing A Madman's Defence was certainly instrumental in provoking the revaluation of personal values during the Inferno period, when Strindberg largely abandoned literature for science and painting. In the former he escapes into a neutral language of chemical formulae and mathematical symbols that precludes identification save eventually of the' calculating... measuring... master builder' (27:494) whose signature he came to recognize in the recurring forms of nature; in the latter, he abandons himself to 'the teleology of chance' (X:215) and carries painting to the verge of non-representation, to the point at which the subject vanishes. Thus in both cases he avoids the type 
of compromising identifications of the Naturalist period and also, as Göran Söderström has suggested, transforms the visible world into a skogssnufvistisk (or modernist) work of art, evolved by a creator whose artistic rationale resembles nothing so much as Strindberg's own. ${ }^{43}$ From the too naked exposure of Naturalist writing a clef, with its merciless treatment of those surrounding his own central figure, he therefore works towards the rehabilitation of fantasy and an art that yields its innermost secrets only to those initiated into the mysticism of everyday life, where 'banal facts' (XI:263) and 'strange chance occurences' are transposed by analogy into meaningful events and a moral order wherein man is no longer, as in Naturalism, continuous with a determining nature that seems to preclude either a basis for personal responsibility or a rationale for pain and suffering, but part of a planned cosmology, in which the earth resembles a place of correction for crimes committed before birth, and men and women are merely one another's tormentors: 'If this existence is already purgatory or an inferno for crimes we have previously committed we are all demons, here to torment each other, and when we are driven against our will to do evil, we are only doing our duty, but suffer all the same from the fact that we have done wrong. This is the double curse of existence. No one has the opportunity of tormenting one another as thoroughly as a man and woman, who love each other (= hate each other) ${ }^{34}{ }^{44}$

Thus his return to literature and to the continuing exposure of himself and others is again authorised, for he is now able to see his own life in its emblematic form as an exemplum or 'warning to others' (28:6) which he considers it his duty to make public, and in place of the no longer tenable role of vivisector he can, as the interpreter of this rediscovered moral order, recognize it as his duty to chastise others as they, indeed, seem so often to chastise him. And just as he had previously found solace in the idea that he had 'sacrificed all the peace of my private life and offered up my whole person for the sheep' (V:356) as 'the preacher, the prophet, the truth teller' (18:313), so the later conception of the writer as a 'scapegoat' is already developed in the confession, 'I struck my own wife, myself! It was a personal sacrifice, which I had to make. But that I struck those who were wretched! That is terrible, but it was perhaps the most essential point of all'. Ultimately, such statements, like the numerous Biblical texts from Ezekiel and Jonah, which come to hand whenever his writer's role perturbs him, serve to ratify his conduct both retrospectively and in later works such as The Dance of Death and Black Banners, in which on one level of the text at least, his material is no less personal than in the Naturalist novels and plays. For in both public and private matters he continues to expose himself and those about him; it is simply that after the Inferno crisis he works within a framework that mitigates his guilt. As he explains, to the poet Gustaf Fröding, '[I] must go forth and prophesy, in spite of the risk of being disavowed like 
Jonah' (XII:316); only now, in the economics of experience he has evolved for his craft, he expects to pay in terms of personal suffering for the use he makes of other lives besides his own.

This, then, is the passion of the writer as it appears to Strindberg, and his suffering is without end because, his periodic schemes to combine literature with some other source of income notwithstanding, there is never any serious doubt that he will continue to appear before the public in words. However, as strategems 'to save my talent from overproduction and my children's future from misere' (VIII:180), to provide the secure and regular income which writing did not yet afford, and to retain the freedom to write as he chose (and for this reason he also resisted the idea of a writer's stipendium as a form of 'commitment which a writer ought not to take upon himself (54:235)), all the possibilities that he entertains as regards an alternative career, whether as banker's clerk (VII:76), language teacher, tourist guide (VIII:180), gardener (V:121), lighthouse keeper (VIII:209), secretary and amanuensis to the theatre director August Lindberg (IX:8), or 'secretary, majordomo, or head waiter in a large hotel' (VII:79) where, like Jean in Miss Julie, he dreams of using his talent for foreign languages, deserve serious consideration both for what they reveal of his general predicament as a writer of exceptional range and ability who was yet unable to live by his pen, and because, as Bo Bennich-Björkman is almost alone in remarking, they 'may well... be related to central conflicts rooted in his life and writing.' 'All Strindberg's plans in this direction have still not been properly studied and seem to be regarded by a number of researchers as no more than passing fancies, ${ }^{35}$ Björkman observes. Seen in the context of the pressures imposed on him by his chosen mode of writing, however, they are illuminating. When, for example, he informs Bonnier that 'one fine day I will advertise for a position in a bookshop, as a correspondent, or for the tenancy of a market garden - I'm quite serious about this', his threat occurs in a letter where he once again describes writing as 'a raw and repulsive occupation' (V:121), and the stability of these alternative ways of earning a living also reflects that underlying concern over the apparently immoral ease and lack of constraint with which art and the artistic life were customarily associated in his mind. 'Everyone worked apart from him,' Johan reflects, in The Son of a Servant: 'When he now compared his dissolute, irregular life, without peace or quiet, to theirs, he considered them both happier and better. Their lives were serious and they carried out their tasks and fulfilled their duties without any hullabaloo or boasting' (18:397), and from the early comedy, Anno' 48, and The Red Room (in which Olle Montanus's words from beyond the grave describe the artistic urge as 'resting upon a broad basis of a desire for freedom, freedom from useful work' (5:357)) to To Damascus III, where the choir of children intones 'Thou shalt feed thyself with the work of thine hands' (29:245), Strindberg is haunted 
by a sense of guilt at the artist's apparent immunity from 'the curse [incurred] in the Fall of Man' (5:357). And hence, against the remarkably constant anxiety which a 'life of poetic idling' (18:364) arouses in him throughout his career, Strindberg also evokes a life of order, of clear moral precepts, firm parameters in a world that is secure, clean, harmonious, and, ultimately, patriarchal. On the one hand, there is the 'unnatural' isolation of 'the unclean bachelor life' (28:252) to which the practice of art seems periodically to reduce him; on the other, a 'natural' world of work and of the home, which promises him membership in a community whose lack has otherwise pained him from his first days at university in Uppsala, when the glimpse through a half-open door of 'a paterfamilias, a mother, and their children about a well-laid table' $(1: 30)^{46}$, revealed a world from which he now felt excluded, and which continues to enchant him even as he attempts and fails to achieve it once again in his relationship with Harriet Bosse, to whom he writes: 'And I only see things in a good light when we three are together. We three, man, woman, child were a world, legitimate, whole, sufficient unto ourselves, and therefore beautiful' (XV:30). ${ }^{47}$

In one form or another, in Master Olof, Getting Married, By the Open Sea, Inferno or To Damascus, the conflict between isolation and community, the creative individual and the family, informs a large part of Strindberg's production, and throughout his work references to matrimony and the family are of course legion. 'The whole of my being rests upon my family' (IV:45), he maintains in 1884, and when he loses the first edition he laments: 'The worst of it is that work, life, business, cease to interest me when I do not have my family to struggle for, and in isolation I die' (VII:49). And yet, as a practising writer, his hold on family life is so demonstrably fragile. 'I was born for family life and a mate - and see what happened!', he exclaims on 6 September 1901 in The Occult Diary: the attempt to be both a writer and a family man repeatedly founders even as it becomes the object of insistent literary scrutiny, in the course of which he evolves the legend of himself as having been 'born out of grace, brought up as life's step child, harried, hunted, in a word, cursed' (29:241) to account for the failure of his 'youthful dream of a house, where peace and purity dwelt' (29:240). Thus, although he would certainly have distinguished himself from the standpoint of those writers (particularly Flaubert, the Goncourts, and Huysmans) who demonstrate their opposition to bourgeois society by rejecting the nineteenth-century cult of the family as inimical to art, Strindberg's predicament emerges, in practice if not in precept, as reminiscent of Flaubert, James, or Kierkegaard, for all of whom writing involves a sacrifice of life itself. ${ }^{48}$

Like Strindberg, too, these writers frequently stressed the complex interplay of forces by which, if art preyed upon other lives, it also fed upon the artist, 
however apparent his detachment from the text he produced. Flaubert, for example, often resorted to the same kind of violent physical image to describe his situation as Strindberg employed to encompass the enforced exposure of his inner life. Just as Strindberg was accustomed to see this as the painful and unsightly baring of his entrails (inälvor), so Flaubert protested: 'Un livre est une chose essentiellement organique, cela fait partie de nous-mêmes. Nous nous sommes arraché du ventre un peu de tripes, que nous servons aux bourgeois, ${ }^{4}{ }^{49}$ and wrote, once more to Feydeau, whose wife was dying: 'Tu as et tu vas a voir de bons tableaux et tu pourras faire de bonnes etudes! C'est chérement les payer. Le bourgeois ne se doutent guère que nous leur servons notre cœur. ${ }^{\prime 50}$ Moreover, the stress on method at the expense of experience in Flaubert's correspondence, and the theory of impassibilité, are in part a response to this situation. For if, as Lukács points out, the division of labour now excludes the writer from living a multifaceted life and isolates him 'as a subject, from all experiences not intended exclusively as the accomplishment of the work, ${ }^{51}$ the consequences are twofold. Firstly, as the experiential capital to hand diminishes, the writer is reduced to the role of observer. Secondly, when he is thus thrown back upon his private life and condemned to observe himself and those close to him, a condition arises (and not only for Flaubert at Croisset) in which it is the work that possesses life while its author, plundered by his creation, is emptied of vitality.

This situation has been conveyed in two striking images. In Illusions perdues, Claude Vigon observes:

Le génie est une horrible maladie. Tout écrivain porte en son cœur un monstre qui, semblable au tænia dans l'estomac, y dévore les sentiments à mesure qu'ils y éclosent. Qui triomphera? la maladie de l'homme, ou l'homme de la maladie? Certes, il faut être un grand homme pour tenir la balance entre son génie et son caractère. Le talent grandit, le cœur se dessèche..$^{52}$

In The Will to Power, meanwhile, Nietzsche, like Strindberg, prefers the vampire to the tapeworm:

Artists are not men of great passion, whatever they may like to tell us and themselves. And this for two reasons: they lack any sense of shame before themselves (they observe themselves while they live; they spy on themselves, they are too inquisitive) and they also lack any sense of shame before great passion (they exploit it as artists). Secondly, however, their vampire, their talent, grudges them as a rule that squandering of force which one calls passion. - If one has a talent, one is also its victim: one lives under the vampirism of one's talent. ${ }^{53}$ 
But like Marx, who has his own vision of the vampire 'in the shade of capital, of dead labour, that dominates and pumps dry, living labour-power', ${ }^{54}$ what both these passages emphasize is that the victories of art seem to be bought by a loss of character, and that this loss may be interpreted in two ways. Most palpably, it has to do with the moral dubiousness of the procedure already examined, in which the writer is obliged to turn his private life to account and encouraged to publicize himself. Irrespective of any autobiographical pact, therefore, the text and its author come to be regarded as commensurate with each other. As Basil Hayward remarks, in The Portrait of Dorian Gray, 'we live in an age when men treat art as if it were meant to be a form of autobiography', ${ }^{55}$ and with the breakdown of that frank and familiar communication between writer and reader on which, for example, Dickens and Thackeray still congratulated themselves ${ }^{56}$ it is as if the reader comes to regard the story as something other than fiction, as if he learns to read it symptomatically as the more or less masked avowal of the writer's private life, a situation conceded even by many of Strindberg's more circumspect contemporaries such as Conrad, who admits: 'A writer of imaginative prose (even more than any other sort of artist) stands confessed in his works. ${ }^{57}$ But there is also a sense in which the seeming shamelessness of the writer, his self-exposure and lack of that moral singleness of character upon which Strindberg so often reflected, is turned back upon itself and the vampire becomes the prey. It is this that Victoria Benedictsson hints at when she observes: 'The people I invent batten upon me like vampires. They leave me hardly a drop of blood, for it is from me - from me they take their life. ${ }^{58}$

These themes, and the conflicts which underlie them, are all revived in Strindberg's final major reckoning with the literary world, Black Banners, a book which is constructed to probe the permissible boundaries of his method and once again to attack the irresponsibility and immorality of his contemporaries in general, and of a way of life which permits a frivolous minority of artists 'to sit here in freedom like this, idle in the morning, while the whole of mankind was working' (41:78) in particular.

The society portrayed in Black Banners is populated by the descendants of his 'red' book, The Red Room, the inhabitants of 'humbug's perverse epoch' (41:32) in which, from values to reputations and from furnishings to opinions, everything is false, pilfered, and a lie: 'Lies in life and ways of living, lies in society, in friendship and love, in legislation, administration, government, politics and religion' (41:185). But what the book stresses is the economic basis by means of which (as he wrote to Schering, shortly after its completion), 'False values are put in circulation, stolen and begged-together reputations circulate, and the entire values of the time become fraudulent' (XV:44), and where it has become the norm 'to write about nothing, to fabricate art without content' 
(41:33). As Martin Lamm remarked, in response to this novel, 'exactly as in Balzac one observes in Strindberg how money is the mystical omnipotent power, which stands behind everything, ${ }^{59}$ and the society depicted in the book is one of predatory animals in a vulgar Darwinist social jungle, creatures who evaluate every relationship in terms of profit and loss. The motif permeates the imagery. 'People were living in a practical age of political economy and did not squander on conversation', the Narrator explains, 'everything is bought nowadays, and merchants appoint professors' (41:5). Thus at the literary dinner with which the novel opens, Professor Stenkåhl's precocious daughter, who is learning fast, inquires of one of the guests 'Listen Kalkbrenner... have you bought pappa, or has he sold himself?' (41:18), while in Stenkåhl's ensuing embarrassment the listening Zachris 'perceived all the economic possibilities inherent in the painful situation' (41:25). Similarly, the Narrator remarks, of Zachris's wife, Jenny: 'Everyone who came to the house got to see her, but not for free. They had to pay with flowers, services, advertisements, feats of nature, and even with ready money' (41:44), while in organizing her funeral it is pointed out that 'Zachris, who for the moment was quoted at a low price on the [literary] market, did not want to risk a fiasco' (41:275).

This economic imagery is associated almost exclusively with Zachris and his circle. It is they, whose dark designs and shady practices are carried through under the black banners of the novel's title, who 'steal each other's thoughts, each other's addresses, each other's friends and one another's identities' (41:10). They live blindly behind their masks, ignorant of an alternative world which the novel also adumbrates, where values are solvent and true. In spite of the glasses which pointedly conceal his eyes rather than improve his sight, Zachris is unable to see this other order of existence which is visible to the group of intellectuals who have withdrawn to a spiritual retreat in the monastery on Siklaön, and which is eventually discerned, if dimly, even by Jenny. 'Eaters of men' and 'executioners' (41:17), these bohemians of the market place regard life 'as a battlefield, and existence as a struggle for bread, position, and woman' (41:288), a battlefield on which Zachris, the vampire, thrives as the most bitter and disturbing of Strindberg's studies of the Alrik Lundstedt-Peer Gynt motif, a merciless analysis of the characterless self, of the writer as 'a selfless jelly' (41:211) who has lost himself by impersonating others and playing every role except his own.

Because Zachris had 'an enormous empty space to fill' (41:48) within himself, he preys on others as 'the racketeer of literature, forming companies for mutual admiration, speculating in reputations... He undertook business trips to publicise himself, had agencies in every corner of the country, formed a company to export himself to Germany... was obliging, in order both to tie the hands of other people and bury his pound, which could be dug up again 
with interest when it suited him' (41:38-9). He places others in his debt in order to exploit them for his private profit, both as material for literary works and as the tools which literature manipulates. He is unable to 'live in and by himself, partly because his 'I' was weak from birth, partly because he had lost it in the course of life, or rather, sold it on fortune's market' (41:41) and hence 'he ate people, ate up their accomplishments, fed upon their private means, and possessed the ability to enter other lives, plough their furrow, so that he confused his person with other people's' (41:48). ${ }^{60}$ Exactly as Strindberg testified to the confusion between fiction and reality in his own experience as a writer, so Zachris loses that firm consciousness of selfhood which is associated with the idea of 'character' that had been scrutinized in The Son of a Servant. 'To have a conscience one must know oneself and be a self,' the Narrator points out, and hence the immorality of the writer, Zachris, who 'had always lived other people's lives, never his own' (41:211). And hence, too, the veiled selfcriticism in the novel, for if Zachris had 'given out roles, made types of himself' (41:211) all his life, he had done no more than Strindberg, who noted, at about this time: 'The poet sits and sees himself in certain scenes. Discovers he has distributed roles'. ${ }^{61}$ The irony is, of course, that it is by means of a fiction that Strindberg, unwittingly or not, suggests the truth about his own failure to tell the truth about himself.

This lack of self is the basis of Zachris's vampirism, his ability to eat his way into other lives and steal other people's thoughts and emotions. But what commences as a long-meditated act of revenge directed by Strindberg against Gustaf af Geijerstam, the writer who he had long regarded as the pilferer of his [Strindberg's] experience eventually develops more far-reaching similarities between the past and practice of its creator, and the methods attributed to his prey. There is of course the evident irony that in selecting a readily recognizable model for the character who is the main target of his satire, Strindberg has written a novel which solicits attention on precisely the interest-seeking grounds it criticizes in Zachris - as Erik Hedén remarked, it was such hardly concealed scandalous personal attacks which made the book 'a unique means of speculation'. ${ }^{62}$ But what is more pertinent is that as always when he was committed to a subject, Strindberg's characters partake of his own flesh and blood (and the tired metaphor is particularly appropriate here), as well as the body and form which others, sometimes unwillingly, lend him, and Zachris is no exception. Indeed, at times his ability to evoke his creator is striking, notably in his compulsion to transform his experiences into literature and write himself free of a troublesome marriage, as Strindberg had done in A Madman's Defence, but also, as Hans Levander has pointed out, ${ }^{63}$ in the often anachronistic reactivation of mnemonic traces which occur in the course of Strindberg's writing the novel, which endow Zachris with a 
substantial layer of experience in common with his creator. The return of a son from a former marriage affords one such episode (it is also recorded in The Occult Diary and Alone) ${ }^{64}$ and material from the lonely winter Strindberg spent on Djursholm in 1891 after his parting from Siri von Essen, is woven into the melancholy Christmas Zachris spends when Jenny leaves him, as well as into the sufferings of the more apparent authorial surrogate, Falkenström. Although projected through the imagery of Strindberg's later point of view, as a potential Swedenborgian vastation on the way to Damascus, this recovery of previous experience provides yet another instance of that jealous reluctance to leave anything he had lived through unutilized, which was so characteristic of Strindberg.

Levander is no doubt correct in suggesting that such material recurs here because Strindberg's animosity towards Geijerstam and Ellen Key (on whom Hanna Paj is modelled) was partly prompted by their failure to respond as he wished to the relationship between his wife and children and the Danish painter (and according to Strindberg, lesbian) Marie David, in 1891. But it is more constructive to see the presence of such material here as a consequence of the conscious parallel which the novel establishes between the destinies of Falkenström and Zachris. Faithful to his normal practice, Strindberg distributes his own experience between more than one character, or constructs characters from material provided by several models. As he remarked, in the suppressed preface to the novel: 'That is what all of us do!... But we are not simply a camera show (biografteater)! We take a few features here and there, we work in mosaic; and when the hero (pardon the expression) is such a lump that he does not hold our interest, I have the right to knead in a little alien clay in order to pad out the match-stick man. ${ }^{65}$ If in most respects it is Falkenström who represents Strindberg in the scheme of the novel, then Zachris is his shadow, and the parallels between them are as essential as their divergencies. As Bertil Romberg observes:

There are several parallel patterns in the novel. Thus Zachris's marriage and its development is paralleled by what is related of Falkenström's marriage. The parallel is underlined by the somewhat complicated position that Zachris has once acquired in Falkenström's marriage, while Falkenström periodically lives as the third party in Zachris's household. ${ }^{66}$

More relevant than these facts, however, is the way in which the two writers react differently to two complementary experiences. This is stressed by the structural juxtaposition of Falkenström's suffering or passion, in Chapter Nine, and the agony of Zachris's Christmas, both of which represent a Swedenborgian vastation, wherein the individual is confronted by his past and provided with the evidence necessary for its correct interpretation, in much the same manner 
as similar experiences form the substance of the key scenes in Strindberg's postInferno drama. Falkenström thereby learns to see matters in a different light. He takes the commonplace, that the earth is hell, literally, and makes his way through the inferno to Siklaön, where he hesitantly undergoes initiation into a new and purer world view similar to the one that Strindberg glosses in the speculations of $A$ Blue Book. That is to say, in the course of Black Banners, Falkenström moves beyond a Naturalist standpoint to accept the existence of another level of reality as it is expressed in one of Strindberg's favourite formulations - it is also inscribed near the head of The Occult Diary:'

'If you want to learn to know the invisible, then observe the visible with the utmost care', the Talmud states. Everyday life is full of mysticism, but you see so badly; and you have to be a Naturalist in order to become mystic. But it is not only a question of being able to spell; you have to join it all together, otherwise you cannot read. (41:200)

Zachris, on the other hand, although offered one of the keys to correct interpretation in the work of Carl du Prel (41:172), from whose Philosophie der Mystik, Strindberg had drawn frequent enlightenment, remains an illiterate. Although it seems to him 'as if the devil himself had written the text today' (41:162) when he flees his isolation in a succession of unhappy encounters among those who might torment him into knowledge, he cannot decipher, in the minutiae of these experiences, a causal connection between events in which the meaning of his life would be spelled out. His life remains a textual enigma and he therefore persists in the blindness now associated with Naturalism, among those who live like the lascivious apes of Strindberg's post Darwinist ancestral nightmare: 'they walk in darkness and wound themselves, they root around in the earth like swine after truffles, they turn their backs upon the archetypes and see only the copies. Therefore they worship Maja, the earth spirit, woman, and when they do not wish to serve God in love they slave under Omphale in hate' (41:185-6).

However, it is their role as writers which forms the essential bond between Zachris and Falkenström. Both take their material directly from life, both are writing novels on living subjects (Zachris on Jenny and Falkenström on Zachris), and early on in the book Falkenström, too, is seen as a vampire 'gaping to swallow something as sweet as a woman's secret' (41:74) or literally biting Jenny's arm (41:65). But if Falkenström's literary exploitation of Zachris appears to be a replica of Zachris's treatment of his wife (and certainly it suggests too self-consciously the way in which the text recording this event is produced), Strindberg is concerned to represent it as something else. Where Zachris remains a Naturalist, Falkenström's entry into the retreat on Siklaön elevates his writing to another dimension. As a refuge from the economic forces 
controlling the production of literature, the monastery represents an ideal that had long fascinated Strindberg, in his letters to Littmansson during the 1890s, in The Cloister, and in To Damascus, ${ }^{67}$ and now that the conception is realised (if only in imagination, and significantly even there, only on the poorly motivated basis of an inheritance which conveniently exempts the members of this fraternity from the importunate demands of earning a living in the market place), it enshrines an approach to experience for which he had long striven: 'This was the place where a few people had saved themselves from despair, turned their back on the world, lowered their demands, and preferred to suffer instead of being revenged' (41:256).

A similar view is advanced in The Ghost Sonata where the old vampire, Hummel, asserts his congenital right to punish and revenge. 'I was born like that - I can't forgive until I have punished. I took it as an imperative duty... and do so still, to clear away the weeds, expose the crimes, balance the books' (45:191). The terms he uses are those under which Strindberg has conducted many a literary campaign; they resemble those under which Zachris conceives the novel he is writing about his wife (41:213-4), and which might as well have been used by Strindberg to account for A Madman's Defence or Black Banners. But when, in The Ghost Sonata the Mummy intervenes at the climax of the second episode and unmasks the formidable Strindbergian unmasker, it is again with an appeal to suffering and repentance that she opposes Hummel's implacable desire for retribution: 'But I can halt time in its course. I can wipe out the past, undo what has been done. Not with bribes, nor with threats, however - but through suffering and contrition' (45:192).

From Inferno onwards these are the qualities on which Strindberg has placed particular stress in order to exonerate himself from the guilt attached to writing books like A Madman's Defence and Black Banners. As he maintains, via Falkenström: 'In order to write my collected works I have sacrificed my biography, my person' (41:196), and in an age when to write is to live precariously upon oneself and of others, suffering and sacrifice are the hostages to fortune by means of which the writer rejects his vampire's role and performs his 'duty as a citizen'. ${ }^{68}$ But as Black Banners demonstrates, the past is not extinguished nor time stopped in its course by suffering or regret, and while the text demonstrates the effectiveness of writing as a means of revenge, it also conveys that it is, for Strindberg at least, an imperfect means of witting selfknowledge. Unwittingly, however, it provides the reader with a text in which to piece together the illusion of Strindberg's hopes and the anxieties as well as the probity of his practice, a practice described in an earlier narrative as one in which, for better or for worse:

the writer takes, takes egotistically, what he comes across; takes an anecdote, which someone tells in his cups, takes a trait from other people's 
lives, which others have lived, takes his thoughts from the philosophers, his comments from the papers, his feelings from imagination, and then he puts his little name to it all and becomes great, and - that's all there is to it! The poet behaves like the boa constrictor: he draws his slime over his prey and then it is his. He spins beautiful nets out of himself so people say - but no one saw how many flies he sucked dry first (15:168). 